Krupskyi, O., Sardak, S., Kolbushkin, Y., \& Stasyuk, Y. (2019). Formation of the Economic Security System of Tourism and Hospitality Enterprises. Journal Of Advanced Research In Law And Economics, Volume X, Issue 4(42), 1159-1175.

DOI: https://doi.org/10.14505//jarle.v10.4(42).16

https://journals.aserspublishing.eu/jarle/article/view/4883

\title{
Formation of the Economic Security System of Tourism and Hospitality Enterprises
}

\author{
Oleksandr P. KRUPSKYI \\ Department of Marketing and International Management, Faculty of Economics \\ Oles Honchar Dnipro National University', Ukraine \\ krupskyy71@gmail.com \\ Sergii E. SARDAK \\ Department of Economics and Management of Tourism \\ Faculty of Tourism and Hotel-Restaurant Business \\ Dniprovskii University of the Humanities ${ }^{2}$, Ukraine \\ dnus@ukr.net \\ Yuriy P. KOLBUSHKIN \\ Department of Marketing, Faculty of Economics and Business Administration \\ National Aviation University ${ }^{3}$, Ukraine \\ tibaltsmerichevsky@gmail.com \\ Yuliia M. STASIUK \\ Department of Marketing and International Management, Faculty of Economics \\ Oles Honchar Dnipro National University ${ }^{1}$, Ukraine \\ stas.yul@gmail.com
}

\begin{abstract}
:
The purpose of the paper is to consider genesis and approaches to forming a security culture of tourism and hospitality enterprises that are superstructures of economic, industrial, professional, household, ecological, psychological and social security. In the research, apart from general scientific methods, we used the collection and analysis of primary information obtained from the survey of 220 respondents. Three areas that have a decisive influence on the security of tourism and hospitality enterprises have been identified: organizational culture, decision-making responsibility, and competitiveness. The decision-making methods for different leadership styles were identified. There were conceptualized connection and strength of correlation between types of strategic decisions, leadership styles and organizational culture of tourism and hospitality enterprises. It has been proposed the factors' configuration relevant to the security of tourism and hospitality enterprises, which focuses on the economic security formation as a function of organizational culture, responsibility for decision making and competitiveness. The styles of leadership and decision-making styles have been revealed, which determine the effectiveness of economic security of tourism and hospitality enterprises.
\end{abstract}

Keywords: tourism; hospitality; enterprise; system; security, culture; style.

JEL Classification: L83, J28, M14, Z10

1 Ukraine, 49000 Dnipro, 35 Yavornitskiy avenue, Oles Honchar Dnipro National University, Department of Marketing and International Management, Faculty of Economics.

2 Ukraine, 49033 Dnipro, 35 Yermolova str., Dniprovskii University of the Humanities, Department of Economics and Management of Tourism, Faculty of Tourism and Hotel-Restaurant Business.

3 Ukraine, 03058 Kyiv, 1 Liubomyra Huzara avenue, National Aviation University, Department of Marketing, Faculty of Economics and Business Administration. 


\section{References}

[1] Antonov, V. A. 2008. Ekonomicheskaya bezopasnost' [Economic security]. Moscow: Izd. House Shumilova II. (in Russian).

[2] Antonsen, S., Nilsen, M. and Almklov, P.G. 2017. Regulating the intangible. Searching for safety culture in the Norwegian petroleum industry. Safety Science, 92: 232-240. DOI: http://dx.doi.org/10.1016/i.ssci.2016.10.013

[3] Balyasniy, M. 2008. Ekonomicheskaya bezopasnost' [Economic security]. Orenburg: Acad. problems of security, defense and law and order.

[4] Bogodistov, Y. Krupskyi, O. P. and Sardak, S. 2016. Dinamicheskiye sposobnosti: sravneniye metodov izmereniya na primere malykh i srednikh predpriyatiy Ukrainy (Dynamic Capabilities: A Comparison of Measurement Methods on the Example of Small and Medium Enterprises in Ukraine). Economic Scope, 110: 139-161. (in Russian).

[5] Bogodistov, Y., Presse, A., Krupskyi, O. P. and Sardak S. 2017. Gendering dynamic capabilities in micro firms. RAE Revista de Administracao de Empresas, 57(3): 273-282. DOl: http://dx.doi.org/10.1590/S0034$\underline{759020170308}$

[6] Bogomolov, V.A. 2009. Ekonomicheskaya bezopasnost' [Economic security]. Moscow: UNITY. (in Russian)

[7] Danilova, E. and Marchenko, V. 2020. Planning of Enterprise Economic Safety on the Basis of SystemStructural Approach. Journal of Advanced Research in Law and Economics, Volume X, Spring, 1(39): 104114. DOI:10.14505//jarle.v10.1(39).11

[8] De Vries, M.F.K. 2003. Dysfunctional leadership. INSEAD. Available at: https://flora.insead.edu/fichiersti wp/inseadwp2003/2003-58.pdf

[9] Elbanna, S. 2006. Strategic decision-making: Process perspectives. International Journal of Management Reviews, 8(1): 1-20. DOI: http://doi.org/10.1111/j.1468-2370.2006.00118.x

[10] Grynko, T.V. 2005. Mekhanizm formuvannya konkurentospromozhnosti vitchyznyanykh pidpryyemstv na mizhnarodnykh rynkakh: Monohrafiya [The Mechanism of Formation of Competitiveness of Domestic Enterprises in International Markets: Monograph]. Kryviy Rih: Publishing House. (in Ukrainian).

[11] Grynko, T. and Krupskyi, O. 2015. Rol' orhanizatsiynoyi kul'tury u stratehichnomu rozvytku pidpryyemstv turyzmu ta hostynnosti [The role of organizational culture in the strategic development of tourism and hospitality enterprises]. Corporate governance: processes, strategies, technologies: collective monograph (pp. 142-167). Kherson, Ukraine: Publishing House "Helvetica". DOI: http://doi.org/10.5281/zenodo.1336884 (in Ukrainian).

[12] Grynko, T., Krupskyi, O., Koshevyi, M. and Maximchuk, O. 2018. Tangible and Intangible Rewards in Service Industries: Problems and Prospects. Journal of Applied Economic Sciences, 13(8): 2481-2492.

[13] Haase, K., Al Abideen, H.Z., Al-Bosta, S., Kasper, M., Koch, M., Müller, S. and Helbing, D. 2016. Improving Pilgrim Safety During the Hajj: An Analytical and Operational Research Approach. Interfaces, 46(1): 74-90. DOI: http://doi.org/10.1287/inte.2015.0833

[14] Halligan, M. and Zecevic, A. 2011. Safety culture in healthcare: a review of concepts, dimensions, measures and progress. BMJ Quality \& Safety, 20(4): 338-343. http://dx.doi.org/10.1136/bmjas.2010.040964

[15] Harrison, E.F. 1996. A process perspective on strategic decision making. Management Decision, 34(1): 4653. DOI: http://doi.org/10.1108/00251749610106972.

[16] Holod, A.P. 2016. Innovative factors of safety and security of regional tourist systems. International Humanitarian University Herald. Economics and Management, 15: 160-163. (in Ukrainian).

[17] Hudson, P.T.W. 2001. Safety management and safety culture: the long, hard and winding road. Occupational Health and Safety Management Systems, 3-32.

[18] Jonas, A. and Mansfeld, Y. 2015. Exploring the interplay between the use of risk-related information, risk perception formation, and the stages of travel product consumption. Current Issues in Tourism, 20(14): 14701488. DOl: http://dx.doi.org/10.1080/13683500.2015.1024104 
[19] Kane, K., Taylor, J.Z. and Teare, R. 2018. Reflections on the theme issue outcomes: Can the culture of safety and quality in organizations be measured and changed? Worldwide Hospitality and Tourism Themes, 10(3): 391-396. DOI: https://doi.org/10.1108/WHATT-02-2018-0016

[20] Kasych, A.O. 2011. Theoretical and methodical grounds for analysis of internal sources for financing of investment activity. Actual Problems of Economics, 3(117): 243-250.

[21] Keropyan, A. and Gil-Lafuente, A.M. 2011. A Fuzzy-Based Decision Model Application on Strategic Management. African Journal of Business Management, 5(15): 6586-6590. Available at: https://pdfs.semantic scholar.org/d168/27709db03d916cdabaa031ece8e00cfd1c93.pdf

[22] Kobyak, M. and Layko, M. 2016. Guidelines for Enhancing the Effective Management of Hotel Enterprises. Journal of Advanced Research in Law and Economics, Volume VI, Spring (11): 104-111.

[23] Kozhukhovskaya R.B. and Udovenko I.O. 2016. Economic Security SME in the Tourism Sector. Scientific Bulletin of Uzhhorod University, Series International Economic Relations and World Economy, 6(2): 6-11.

[24] Krupskyi, O. 2014. OsobennostistrukturyzanyatostinaturisticheskikhpredpriyatiakhUkrainy. Presented at Opportunities for Tourism Development: International and Local Experience, All Ukrainian AcademicPractical Conference, Zaporizhzha: TOV "LIPS." (in Ukrainian).

[25] Krupskyi, O.P. 2017. Osoblyvosti orhanizatsiy i systemy ekonomichnoyi bezpeky na pidpryyemstvakh turyzmu i hostynnosti [Specifics of Organization of an Economic Security System in Tourism and Hospitality Firms]. Modern transformations of organizational and economic mechanism of management and logistics of subjects of entrepreneurship in the system of economic security of Ukraine: collective monograph, 373-389. Dnipro, Ukraina: Bila K. O. http://doi.org/10.5281/zenodo.1336640 (in Ukrainian).

[26] Krupskyi, O.P. and Grynko, T. 2018. Role of Cognitive Style of a Manager in the Development of Tourism Companies Dynamic Capabilities', Tourism and Hospitality Management, 24(1): 1-21. DOI: https://doi.org/10.20867/thm.24.1.5

[27] Krupskyy, A. 2014. Modern Methods of Management Decision-Making and their Connection with Organizational Culture of the Tourism Enterprises in Ukraine. Economic Annals-XXI. 7-8(1): $95-98$ (in Ukrainian).

[28] Krups'kyy, O.P. and Kobchenko, A.A. 2015. Orhanizatsiyna kul'tura yak chynnyk ekonomichnoyi bezpeky turystychnoho pidpryyemstva [Organizational Culture as a Factor of Economic Security of the Tourist Enterprises]. International Humanitarian University Herald. Economics and Management, 10: 149-152. http://doi.org/10.5281/zenodo.1336636 (in Ukrainian).

[29] LaGuardia, D. 2000. Organizational Culture Authenticity Consulting. Online Integrated Library for Personal, Professional and Organizational Development, LLC. Available at: http://managementhelp.org/ organizations/culture

[30] Linkov, I., Varghese, A., Jamil, S., Seager, T.P., Kiker, G. and Bridges, T. 2004. Multi-Criteria Decision Analysis: A Framework for Structuring Remedial Decisions at Contaminated Sites. Comparative Risk Assessment and Environmental Decision Making, 15-54. DOI: http://doi.org/10.1007/1-4020-2243-3_2

[31] Mador, M. 2000. Strategic decision making: opportunities for research. Kingston Business School, Kingston University.

[32] Mazaraki, A. and Vedmid, N. 2013. Semantic Modelling of Service Management of Sanatorium Resort and Health Enterprises. Economic Annals-XXI, 7-8(1): 80-82.

[33] McCarthy, D.J., Puffer, S.M. and Darda, S.V. 2010. Convergence in Entrepreneurial Leadership Style: Evidence from Russia. California Management Review, 52(4): 48-72. DOl: http://doi.org/10.1525/cmr.2010.52.4.48

[34] Mostafa, R.B. and Hefny, L.I. 2016. Exploring the Mediating and Moderating Role of Services Marketing Strategy and Safety and Security Measures in the Tourism Industry. International Journal of Customer Relationship Marketing and Management, 7(1): 1-26. DOI: http://dx.doi.org/10.4018/ijcrmm.2016010101

[35] Motamedi, K. 2006. Seven neurotic styles of management. Graziadio Business Review, 9(4). Available at: https://gbr.pepperdine.edu/2010/08/seven-neurotic-styles-of-management/ 
[36] O'Reilly, C.A., Chatman, J. and Caldwell, D.F. 1991. People and Organizational Culture: A Profile Comparison Approach to Assessing Person-Organization Fit. Academy of Management Journal, 34(3): 487516. DOI: http://dx.doi.org/10.2307/256404

[37] Papatheodorou, A. and Pappas, N. 2016. Economic Recession, Job Vulnerability, and Tourism Decision Making: A Qualitative Comparative Analysis. Journal of Travel Research, 56(5): 663-677. http://dx.doi.org/10.1177/0047287516651334

[38] Petyuh, V. and Ilnitskaya, O. 2012. Metodychni pidkhody do diahnostyky prychyn vysokoyi plynnosti kadriv v orhanizatsiyi [Methodical Approaches to Diagnostics of Causes of High Literacy of Persons in Organization]. http://doi.org/10.5281/zenodo.1332050 (in Ukrainian)

[39] Pizam, A. and Mansfeld, Y. 2006. Toward a Theory of Tourism Security. Tourism, Security and Safety, 1-27. DOI: http://dx.doi.org/10.1016/b978-0-7506-7898-8.50004-7

[40] Reason, J. 1998. Achieving a safe culture: Theory and practice. Work \& Stress, 12(3): 293-306. DOl: http://dx.doi.org/10.1080/02678379808256868

[41] Reisinger, Y. and Mavondo, F. 2006. Cultural Differences in Travel Risk Perception. Journal of Travel \& Tourism Marketing, 20(1): 13-31. DOI: http://dx.doi.org/10.1300/j073v20n01_02

[42] Sardak, S. and Samoylenko, A. 2014. National Economies Intellectualization Evaluating in the World Economy. Economic Annals-XXI, 9-10(2): 4-7.

[43] Sardak, S., Radziyevska, S. and Prysiazhniuk, Y. 2019. Civilizational structure of regional integration organizations. Przeglad Strategiczny, 12, 59-79. DOI: 10.14746/ps.2019.1.4

[44] Sellers, R. 2014. A professional culture of safety - The influence, measurement and development of organisational safety culture. ISASI 2014 Seminar, October 2014, Adelaide, Australia, 1-11. Available at: http://www.isasi.org/Documents/library/technical-papers/2014/ISASI\%202014\%20-\%20Sellers\%20-\%20 Safety\%20culture.pdf

[45] Sharpanskykh, A. and Stroeve, S.H. 2011. An agent-based approach for structured modeling, analysis and improvement of safety culture. Computational and Mathematical Organization Theory, 17(1): 77-117. DOI: http://dx.doi.org/10.1007/s10588-011-9083-9

[46] Shvachych, G., Moroz, B., Pobocii, I., Kozenkov, D. and Busygin, V. 2019. Automated control parameters systems of technological process based on multiprocessor computing systems. In Science and Information Conference, 666-688. Springer, Cham.

[47] Slyvenko, V.A. 2013. Innovative approaches to solving the security problems in the tourism. European Journal of Management Issues, 21(2): 44-49. DOI: http://dx.doi.org/10.15421/191307. (in Ukrainian).

[48] Tkachenko, A. and Reznikov, O. 2010. Otsinka rivnya ekonomichnoyi bezpeky pidpryyemstva [Estimation of the level of economic security of the enterprise]. Bulletin of the Economic Science of Ukraine, 1: 101-106. (in Ukrainian).

[49] Turner, B.A., Pidgeon, N., Blockley, D. and Toft, B. 1989. Safety culture: its importance in future risk management. In Position paper for the second World Bank workshop on safety control and risk management, Karlstad, Sweden, 6-9.

[50] Vasilescu, C. 2011. Effective Strategic Decision Making. Journal of Defense Resources Management, 2(1): 101-106.

[51] Velychko, O. and Velychko, L. 2017. Logistical modelling of managerial decisions in social and marketing business systems, Journal of International Studies, 10(3): 206-219. DOI: http://dx.doi.org/10.14254/2071$\underline{8330.2017 / 10-3 / 15}$

[52] Veretekhina, S., Medvedeva, A., Vinichenko, M., Demchenko, T., Karyagina, T. and Makushkin, S. 2017. Current Trends Influencing the Competitiveness of International Tourism. Journal of Advanced Research in Law and Economics, Volume VIII, Spring, 2(24), 658 - 669.

[53] Wainfan, L. 2010. Multi-Perspective Strategic Decision-Making Principles, Methods, and Tools. Pardee RAND Graduate School dissertation series, Available at: http://www.rand.org/content/dam/rand/pubs/rgs dissertations/2010/RAND_RGSD260.pdf 
[54] Wally, S. and Baum, J.R. 1994. Personal and Structural Determinants of the Pace of Strategic Decision Making. Academy of Management Journal, 37(4): 932-956. DOI: http://dx.doi.org/10.2307/256605

[55] Wang, B., Wu, C. and Huang, L. 2017. Emotional safety culture: A new and key element of safety culture. Process Safety Progress. DOI: http://dx.doi.org/10.1002/prs.11953.

[56] Westrum, R. and Adamski, A.J. 1999. Organizational Factors Associated with Safety and Mission Success in Aviation Environments. In D. J. Garland, J. A. Wise \& V. D. Ilopkin (Eds.) Handbook of Aviation Human Factors. Lawrence Erlbaurn, Mahwah, NJ.

[57] Wickramasinghe, V. S. K., and Takano, S. E. 2009. Application of Combined SWOT and Analytic Hierarchy Process (AHP) for Tourism Revival Strategic Marketing Planning. In Proceedings of the Eastern Asia Society for Transportation Studies, 7: 189-189.

[58] Zimmerman, P.B. and Kanter, R.M. 2012. Decision-Making for Leaders. A Synthesis of Ideas from the Harvard University Advanced Leadership Initiative Think Tank. Cambridge, MA. March 29-31, 30 p. Available at: http://advancedleadership.harvard.edu/Portals/115252/docs/Decision_Making_ThinkTank_Final.pdf

[59] ${ }^{* * *}$ CBI. 1991. Developing a Safety Culture. Confederation of British Industry, London.

[60] ${ }^{* * *}$ IEP. 2019. Global Peace Index 2019. Vision of Humanity. Available at: http://visionofhumanity.org/ app/uploads/ 2019/06/GPI-2019-web003.pdf

[61] ${ }^{* * *}$ State Statistics Service of Ukraine. 2018. Turystychna diyalnist' v Ukrayini v 2017 r. Available at: http://www.ukrstat.gov.ua/druk/publicat/kat_u/2018/zb/05/zb_td_2017.pdf. (in Ukrainian).

[62] *** UNWTO. 2019. International Tourism Highlights, 2019 Edition. Available at: http://dx.doi.org/10.18111/9789284421152

[63] ${ }^{* * *}$ WTO. 1996. Tourist Safety and Security, Practical Measures for Destinations, WTO-1996. Available at: https://www.e-unwto.org/doi/pdf/10.18111/9789284401529 